INTERNATIONAL JOURNAL OF

SYSTEMATIC BACTERIOLOGY

Vol. 16, No. $3 \quad$ July 1966

pp. $341-369$

\title{
PROPOSED EMENDATIONS OF THE \\ INTERNATIONAL CODE OF NOMENCLATURE OF BACTERIA AND VIRUSES - WITH COMMENTS
}

Compiled by the Editorial Board of the Judicial Commission of the International Committee on Bacteriological

Nomenclature - IAMS

Item 1. The title of this Code is "The International Code of Nomenclature of Bacteria."

Comment: The present title of the Code is International Code of Nomenclature of Bacteria and Viruses. The present title was adopted in 1953 at the Rome International Microbiological Congress. By action of the Executive Committee of the International Association of Microbiological Societies (IAMS), the International Subcommittee on the Nomenclature of Viruses has been replaced by a new committee coordinate with the International Committee on Bacteriological Nomenclature. This committee will be constituted at the 1966 IXth Congress for Microbiology in Moscow. It is anticipated that this new International Committee will formulate a Code of Nomenclature for the Viruses. It is no longer appropriate that the name "viruses" be included in the name of the Bacte riological Code.

Item 2. The word virus (or viruses) will be deleted from the bacteriological code wherever there is implicit the assumption that nomenclature of the viruses is included.

Comment: The deletions have been approved by Sir Christopher Andrewes, formerly chairman of the International Subcommittee for Nomenclature of Viruses and currently chairman of the Provisional Committee on Viruses which is to report at Moscow. The deletions will be noted in subsequent Items where pertinent.

Item 3. Emendation of General Consideration 1 (page 3) to

read as follows:

"The progress of bacteriology can be furthered by a precise system of nomenclature which is properly integrated with the systems used by botanists, zoologists and virologists, and accepted by the majority of bacteriologists in all nations. The International Code of Nomenclature of Bacteria applies to bacteria and related organisms. Botanical, zoo- 
logical and virological codes provide for the nomenclature of certain other microbial groups, such as yeasts and fungi, algae, protozoa and viruses."

Item 4. Emendation of General Consideration 2 (page 5).

Reword the first three lines to read:

"The precepts on which this system of nomenclature of bacteria is based are divided into Principles, Rules and Recommendations."

Comment: Change in wording deletes reference to "viral nomenclature."

Item 5. Emendation of General Consideration 2 (page 5).

Insert the following after line 11:

"The rules of nomenclature do not govern the delimitation of taxa nor determine their interrelationships. They do not limit taxonomic freedom in orderly classification. They primarily assess the correctness of names applied to defined taxa."

Comment: The emended paragraph reads:

"The rules in general are retroactive; names of forms of nomenclature contrary to a rule (illegitimate names or forms) cannot be maintained. Certain rules authorize appendices and define their scope and authority. The rules of nomenclature do not govern the delimitation of taxa nor determine their interrelationships. They do not limit taxonomic freedom in orderly classification. They primarily assess the correctness of names applied to defined taxa."

Item 6. Emendation of Principle 2 (page 9). Insert the word "are" between "rules" and "doubtful."

Comment: Correction of a typographical error. The statement reads:

"In the absence of a relevant rule, or where the consequences of rules are doubtful, established custom must be followed. In case of doubt, a resumé in which all pertinent facts are outlined should be submitted to the Judicial Commission for an Opinion."

Item 7. Emendation of Principle 3 (page 9). Revise to read as follows:

"Nomenclature of bacteria and the nomenclature of algae and fungi, of protozoa, and of viruses, a re interdependent in the sense that the name of a bacterial taxon is to be rejected if it is a later homonym of the name of a taxon of 
algae, fungi, protozoa or viruses. Nomenclature of bacteria is independent of botanical nomenclature (algae and fungi excepted) and of zoological nomenclature (protozoa excepted)."

Comment: Revision is required, inasmuch as the Code no longer applies to nomenclature of viruses.

Item 8. Emendation of Principle 4 (page 11).

Comment: Principle 4 was emended at the VIIIth International Microbiological Congress at Montreal. It has not been published in the printed Code. The Rule was emended by addition of a sentence (the last) to read as follows:

"Scientific names of all taxa are usually taken from Latin or Greek. When taken from any language other than Latin or formed in an arbitrary manner, they are treated as if they were Latin. Latin terminations should be used as far as possible for new names. The classic Latin rules for latinization of Greek and other words of non-Latin origin should be followed."

No action is required.

Item 9. Emendation of Principle 5 (page 12). Reword to read as follows:

"Nomenclature deals with

(1) The terms which denote the categories of taxa, such

as species, genus, family and the relative ranks of the se categories.

(2) The names which are applied to the individual taxa, such as Bacillus subtilis, Streptococcus, Spirillaceae, Spirochaetales."

Comment: Editorial deletion of the superfluous phrases "taxonomic groups or units" and "taxonomic groups."

Item 10. Emendation of Principle 7 (page 12). The emendations of Principle 7 were approved at the VIIIth International Microbiological Congress at Montreal. Principle 7 was emended to read as follows:

"The terms which denote the rank of taxa are defined as follows:

(a) Every individual is treated as belonging to a number of categories of consecutive rank and consecutively subordinate: of these the species is the basic one. The principal categories in ascending sequence are species (species), genus (genus), family (familia), order (ordo), class (classis), division (divisio). In some genera the rank subgenus (subgenus) may be distinguished, and in some families the rank tribe (tribus). 
(b) In some genera, in descending sequence, there are recognized sections, subsections, series and subseries. These taxa are placed between subgenus and species.

(c) In many species, subspecies or varieties are distinguished; in some cases infrasubspecific subdivisions of a species such as formae speciales, strains, groups, serotypes, variants, phases and others may be recognized.

(d) If a greater number of intermediate categories (ranks) are required, the terms for these subdivisions are made by adding the prefix "sub-" to the terms denoting the ranks. Thus, subfamily denotes a rank between a family and a tribe, subtribe a rank between a tribe and a genus, etc.

(e) The definition of each of these categories (ranks) varies, up to a certain point, according to individual opinion and the state of the science; but their relative order, sanctioned by custom, must not be altered. No classification is admissible which contains such alterations.

Note. A summary of the names of the categories of taxa that may be recognized in the Bacteriological Code is given below. Those names that should be recognized where pertinent in taxonomy of bacteria are printed in bold-face type. Those which are optional are printed in Roman. The equivalent Latin is given in parentheses.

1. Division (Divisio)

2. Subdivision (Subdivisio)

3. Class (Classis) 4. Subclass (Subclassis)

5. Order (Ordo) 6. Suborder (Subordo)

7. Family (Familia)

8. Subfamily (Subfamilia)

9. Tribe (Tribus)

10. Subtribe (Subtribus)
11. Genus (Genus)

12. Subgenus (Subgenus)

13. Section (Sectio)

14. Series (Series)

15. Subseries (Subseries)

16. Species (Species)

17. Subspecies (Subspecies)

17a. Variety (Varietas)

18. Infrasubspecific forms

19. Individual (Individuum)"

Item 11. Emendation of Principle 8 (page 15). Substitute the word "taxon" for the phrase "taxonomic group."

Principle 8 will then read:

"The primary purpose of giving a name to a taxon is not to indicate the characters or the history of the name of the taxon but to apply a means of referring to it."

Comment: Approved at the VIIIth Microbiological Congress at Montreal, but not published in the Code. 
Item 12. Emendation of Principle 11 (page 17). Approved at the VIIIth Microbiological Congress at Montreal, to read as follows:

"The application of the names of taxa is determined by means of nomenclatural types. A nomenclatural type is that constituent element of a taxon to which the name of the taxon is permanently attached, whether as the accepted name or as a synonym."

Item 13. Further emendation of Principle 11 (page 17).

The addition of the following Note is proposed:

Note: The phrase "constituent element of a taxon" for a species or a subspecies of bacteria is the type specimen, usually a type strain or culture.

Comment: The Note is proposed to make clear that the "nomenclatural type" is the name applied to the type taxon.

\section{Emendation of Rules and Recommendations of the Code}

Item 14. General statement relative to editorial revision of Rules $1,2,3,4,5 a, 6,7$, and Recommendation $2 a$.

The Montreal Congress approved emendation of Rules 1 , $2,3,4,5 a, 6,7$ and Recommendation $2 a$, by requiring that the rules be phrased in the singular number rather than in the plural.

Item 15. Emendation of Rule 1 (page 21) (see Item 14).

Emended to read:

"The name of each taxon above the rank of genus is a substantive or an adjective used as a substantive, of Greek or Latin origin, or a latinized word, in the feminine gender and in the plural number."

Item 16. Emendation of Rule 2 (page 21) (see Item 14).

Emended to read:

"The name of each taxon above the rank of family is taken preferably from a combination of characters covering the nature of the taxon as closely as possible, or from a single character of outstanding importance."

Item 17. Emendation of Recommendation 2a (page 21).

Emended to read:

"The name of a new order or of a suborder should preferably be based upon the name of the type genus of a contained family." 
Item 18. Emendation of Rule 3 (page 22). Emended to reàd:

"The name of a taxon between suborder and genus is formed by the addition of the appropriate suffix to the stem of the name of the type genus."

Item 19. Emendation of Rule 4 (page 24). Emended to read:

"The name of each taxon between subclass and genus has a suffix to fix its taxonomic rank. The suffix for an order is -ales, for a suborder -ineae, for a family -aceae, for a subfamily -oideae, for a tribe -eae, and for a subtribe -inae."

Item 20. Emendation of rule 5a (page 26). Emended to read:

"The name of a genus or a subgenus is a substantive (or an adjective used as a substantive) in the singular number, and written with an initial capital. The name may be taken from any source whatever and may even be composed in an arbitrary manner. It is treated as a Latin substantive."

Item 21. Emendation of Rule 5 by addition of 5d. Approved by Montreal Congress.

(new) 5d. "When a genus is so subdivided as to include sections, subsections, series and subseries, the names of the se taxa are formed as follows:

(1) The name of a section is preferably either a descriptive adjective in the plural number agreeing in gender with that of the name of the genus, or the plural of the specific epithet of the name of one of the species included in the taxon."

(2) The name of a subsection, series, or subseries, is preferably the plural of the specific epithet of one of the species included in the taxon.

(3) Within the same genus no two sections, subsections, series or subseries, may bear the same name.

Note 1: The names given to sections, subsections, series and subseries do not compete with names of genera and subgenera as to priority or homonymy.

Note 2: The names of the subdivisions in the form of plural adjectives are treated as plural nouns (substantives). They resemble in this respect the names of suprageneric taxa which are in the form of plural adjectives but are also regarded as plural nouns." 
Item 22. Emendation of Recommendation 5a (page 30).

First sentence to read as follows:

"Bacteriologists who are forming a new generic or subgeneric name should attend to the following recommendation"

Item 23. Emendation of Rule 6 (page 33). Emended at the

Montreal Congress to read as follows:

"The name of a species is a binary combination consisting of the name of a genus followed by a single specific epithet. If an epithet consists of two or more words, these must either be united or hyphenated.

Note 1. A specific epithet consisting of two or more words not joined by hyphens when originally published is not to be rejected, but, when used thereafter, the words are to be hyphenated or joined.

A specific epithet is:

(1) An adjective, which must agree grammatically with the generic name, or

(2) A substantive, in the nominative, in apposition with the generic name, or

(3) A substantive in the genitive.

A specific epithet may be taken from any source whatever and may even be composed arbitrarily. Within the same genus, no two species names may bear the same specific epithet.

Note 2. The term epithet, as used here, implies a single descriptive word or a single descriptive phrase consisting of two or more words. If the author of the name of the species proposed an epithet consisting of two or more words, but without hyphenating or joining, the form is to be corrected, but without prejudice.

Note 3. The elements of a compound specific epithet should be separated by hyphens if separately declined. If not separately declined they should be united."

Item 24. Emendation of Recommendation 6b (7) (page 40).

Emended at the Montreal Congress to read:

"To avoid compound specific epithets which include word stems from two or more languages (epitheta hybrida). This does not apply to hyphenated specific epithets, in which the components are separately declined."

Item 25. Emendation of Rule 7 (page 44). Emended at the Montreal Congress to read:

"The name of a subspecies (variety) is a ternary combi- 
nation consisting of the name of a genus followed by a specific and a subspecific epithet in order.

"An epithet of a subspecies (variety) is formed like that of a species; when adjectivel in form and not used as a substantive, it agrees in gender with the generic name.

"Neither within the same species nor within the same genus may two subspecies bear the same subspecific epithet.

"If the species is divided into subspecies, the subspecific epithet of the subspecies, including the type of the species, must be the same as that of the species."

Item 26. Emendation of Rule 8 (page 34).

A tentative proposal for emendation of Rule 8 was made at the Montreal Congress (1962). It was agreed that there was insufficient time for adequate discussion. The Permanent Secretaries and Chairman were asked as a result of correspondence to redraft, if necessary, the proposal for late $i$ consideration. The following draft proposal is presented.

"Rule 8. Names of infrasubspecific subdivisions (infrasubspecific forms). An infrasubspecific subdivision is a taxon having a lower rank than a subspecies. An infrasubspecific form is one of the coordinate designations within an infrasubspecific taxon. The names (terms) used to designate the infrasubspecific subdivisions generally recognized are strain, isolate, forma specialis, biotype, serotype, morphotype, phagotype, lysotype, phase, group. Less commonly used are the names (terms) state, stage, chemovar, chemotype, cultivar.

An infrasubspecific form within a species is designated by the name of the species followed by the terms used to designate the infrasubspecific subdivision (as serotype strain), this in turn by the infrasubspecific designation or epithet. This may be a Latin or latinized word, a vernacular name or word, a number, a letter or a formula intended to characterize the form.

The complete citation of the name of an infrasubspecific form includes the binary combination of the species name followed by the term designating the infrasubspecific subdivision, this in turn by the epithet (or epithet substitute) of the infrasubspecific form and this by the name of the author.

A Latin or latinized infrasubspecific name may be elevated by a subsequent reviser to the status of subspecies or species. If so elevated, it ranks in its new status, for purposes of priority, from the date of its elevation, and is to 
be attributed to the author by whom it was elevated (from Bradley draft).

Type strains (cultures) of significant infrasubspecific forma may be designated. The designations or epithet used in naming infrasubspecific forms are coordinate within each subdivision, but not with the names of species of subspecies."

Item 27. Preference as to use: phagotype and lysotype (Rule 8).

The Permanent Secretaries were requested to refer the question of preferred use to the two international bacteriophage subcommittees through their secretaries for consideration.

Item 28. Emendation of Recommendation 8a (page 48).

Emendation approved at Montreal (1962). The statement approved at Montreal did not contain the terms "isolate" and "cultivar" which were later suggested and are not approved. The emendation reads:

"Authors of names of infrasubspecific subdivisions of species of bacteria should attend to the following recommendations and definitions:

(1) A strain is made up of the descendants of a single isolation in pure culture. It may be designated in any manner, as by the name of the individual responsible for its isolation (as Corynebacterium diphtheriae strain Park-Williams); by the name of a locality, by a number, or by some similar laboratory distinguishing mark.

"Strain" may also be used to designate cultures of bacteria which correspond to cultivated 'varieties' (cultivars) of higher plants, and which have some special economic significance.

(2) A special form (forma specialis) is an infrasubspecific form included in an infrasubspecific subdivision of a species of a parasitic, symbiotic or commensal microorganism distinguished primarily by adaptation to a particular host or habitat. It is named, preferably, by use of the scientific name of the host written in the genitive. (3) Type is a term which has frequently been used incorrectly to designate a subdivision of a species, particularly in cases where the distinguishing characters are regarded as insufficient to justify the recognition of a subspecies. The term "type" in bacteriology (as throughout biology) should be used strictly in the sense defined 
in Principle 11 and Rule 9. It should not be used to designate infrasubspecific forms based on antigenic characters.

It is recommended that wherever appropriate the following terms be used to designate infrasubspecific subdivisions of a species:

Strain, forma specialis, isotype, biotype, serotype, morphotype, lysotype (phagotype), phase, group. Less commonly used are the names (terms) state, stage, chemovar, chemotype and cultivar.

It is recommended that the term serotype (or serological type) be used for infrasubspecific forms based upon antigenic characters.

It is recommended that the term biotype (or physiological type) be used for infrasubspecific forms based upon differences in physiological or biochemical characteristics.

It is recommended that morphotype (or morphological type) be used for infrasubspecific forms based on noteworthy differences in morphological characteristics.

It is recommended that lysotype (phagotype or phage type) be used for infrasubspecific forms based on relationships to bacteriophages.

(4) The designation "phase" should be restricted to welldefined stages of naturally occurring alternating variations.

(5) The term "group" in bacteriology should be used with great care and be well-defined if ambiguity is to be avoided. It has been used in somewhat different senses by those in various fields in bacteriology. "Group" may be appropriately used to designate congeries of organisms having common characteristics. In many cases the groups are based upon antigenic analysis. They are assemblages of related serotypes. The term "group" has in some cases been employed to avoid the use of the correct nomenclatural name of a taxon such as genus or species. This use leads to confusion and should be avoided.

(6) State (or stage) is the name given to the rough, smooth, mucoid and similar varients which arise in cultures in many species of bacteria. These are usually regarded as alternating states which are often reversible and, indeed, by some authors, considered as part of a pleomorphic life cycle. They may be designated by some vernacular descriptive name. 
(7) The term "chemovar" (chemotype) may be used to designate infrasubspecific subdivision to include infrasubspecific forms or strains characterized by production of some chemical not normally produced by the type strain of the species.

Item 29. Emendation of Rule 9a (page 53). There has been some confusion in the literature of bacteriology concerning the distinction between terms "types" and "nomenclatural type." The following is proposed as an attempt to clarify. It has not been approved or presented previously. The proposed emendation reads:

"Rule 9a. For each taxon there shall be designated a type. The nomenclatural type is that constituent element of the taxon to which the name of the taxon is permanently attached. The type of a species or infraspecific taxon is preferably a designated type strain or in special cases it may be a preserved specimen or preparation or an illustration. The type of a genus is a species within the genus designated in conformity with Rule 9c. The type of family or subfamily, tribe or subtribe, is the genus on whose name the name of the higher taxon is based. The type of a taxon higher than family should be fixed at the time of its proposal by its author. If not fixed by the author it may be designated by the Judicial Commission.

Item 30. It was suggested at Montreal that a rule be adopted as follows:

"The type of a section, subsection, series or subseries, shall be a species and its selection shall be governed by the rules for the selection for the genera and subgenera as outlined in Rule $9 c(1),(2)$ and (3)."

Comment: If a rule is approved it should be termed Rule $9 c(4)$. See Item 21 which gives in detail the method of naming sections, subsections, series and subseries. The suggested emendation above may not be applicable. The following suggestion, not a proposal, may be helpful:

"A section may be named by its author either (1) by proposing a descriptive adjective, in which case the author should designate the type species, or (2) by proposing the plural of the specific epithet of one of the included species, which is thereby designated as the type species. A subsection, series or subseries may be named by proposal by an author of the plural of the specific epithet of a contained species, which species is thereby designated as the type species." 
Item 31. Emendation of Rule 9d (page 56). It is proposed that Rule 9d, as approved at the Montreal Congress, be emended to read:

Rule 9d (1). "The type of a species, subspecies, or an infrasubspecific form is preferably a living culture (strain) maintained in a bacteriological laboratory, more particularly in one of the internationally recognized collections of type cultures.

Note 1. For a species which cannot be maintained in laboratory cultures or for which neither type cultures nor neotype cultures exist, the type is the original description, preparation or illustration.

Note 2. Definitions:

(a) The term culture is to be interpreted as including every method of maintaining organisms in a living state (in a medium, in a host by passage, in cells or exudates, frozen or desiccated).

(b) A type culture is a living culture of an organism which is a descendant of the original culture or an isolation from which the author who first described and named the organism made his original description, which culture has been maintained pure, and which agrees in its characters with the original description.

(c) A neotype culture is one which has been accepted by international agreement to replace a type culture which is no longer in existence. It should agree with the diagnosis given by the original describer and should be recommended by those workers familiar with the species, and their agreed recommendation approved by the Judicial Commission.

(d) A reference strain is a culture (strain) which is neither a type strain nor a neotype strain, but which is used by an author as a standard in a study of a related group of organisms. A reference strain has no nomenclatural status."

Rule 9d(2). "If the author in the original publication of the name of aspecies, subspecies or of an infrasubspecific form definitely designated a type culture (strain), or if the author described only a single strain, this shall be accepted as the type culture (strain) regardless of other considerations (original designation).

Note. The meaning of the expression "definitely designated as a type culture" is to be rigidly construed."

Rule 9d(3). "If the author in the original publication of the name of a species, subspecies or infrasubspecific form 
failed to designate a type culture(strain), a type culture may be designated by a subsequent author, and the author who first makes the choice must be followed."

Item 32. Emendation of Rule 11 (page 61). At Montreal Rule 11 was emended by addition of a statement relative to publication of names and descriptions in patents and patent applications. Rule 11 with the emendation reads:

"Publication is effected under this code by sale or distribution of printed matter to the general public or to bacteriological institutions. No other kind of publication is accepted as effective (effective publication). Communication of new names at a public meeting or scientific conference does not constitute effective publication. The inclusion of a name or description or both in a patent application or in a patent does not constitute effective publication."

Comment: Dissatisfaction by manufacturers of antibiotics has been expressed to this denial of effective publication to names and descriptions in patent applications and issued patents. Dr. J. B. Routien, on behalf of several of the manufacturers of antibiotics and their employed taxonomists submitted to Dr. Clark as one of the Permanent Secretaries of the International Committee on Bacteriological Nomenclature a proposal for emendation of Rule 11 . The proposal is to delete the present sentence of Rule 11 which reads:

"The inclusion of a name or description or both in a patent application or in a patent does not constitute effective publication."

He proposed replacement of the deleted sentence by the following emendation:

"The names of any Schizomycetes that appear with their corresponding descriptions in any patent application or issued patent from any country shall be considered to have been published effectively. Publication is not effected in those countries in which the printed material of the patent contains no description of the organism, nor is it effected in those countries in which neither claims nor specifications are printed."

Dr. Routien's letter and accompanying statement is too long for inclusion. He enumerates five reasons for the requested change. His letter is accompanied by several documents. These will be available at the meeting of the Judicial Commission and the ICBN at the Moscow Congress. Somewhat later it was proposed by Dr. Routien that there be a conference under the Chairmanship of Dr. Clark as a Permanent 
Secretary at the time of the meeting of the American Society for Microbiology in Los Angeles to discuss the proposed emendation. A meeting was held in Los Angeles, Cal ifornia, attended by officials from antibiotic companies. The Chairman of the Judicial Commission was asked to attend the conference together with several individuals interested in bacteriological nomenclature. The conference was held in the Hotel Biltmore on the evening of Sunday, May lst. The request was considered at length and the difficulties of carrying out its provisions were pointed out. After prolonged discussion, a second proposal was developed, as follows:

Delete from Rule 11 the phrase "or description or both" from thelast sentence, which would then read:

"The inclusion of a name of a new taxon of bacteria in a published patent application or issued patent does not constitute effective publication."

Include the following new statement in Rule 12 relative to Valid Publication:

"The name of a taxon or bacteria not effectively published in a patent application or in an issued patent may be validly published by subsequent publication of a name in conformity with Rule 11 , provided such publication is accompanies by a description of the taxon or by reference to a previously and effectively published description. The date of issuance of the patent shall be included and is recognized as the date of publication."

Item 33. Emendation of Rule 12c (page 65). Proposed to emend the Note to Rule $12 \mathrm{c}$ by the addition to the last sentence of the following:

"That is, who does not state clearly that he is proposing a new name or combination."

The Note as emended would read:

"Note. Number (1) does not apply to names or epithets published with a question mark or othe $r$ indication of taxonomic doubt, yet published and accepted by the author. By "incidental mention" of a new name or combination is meant mention by an author who does not intend to introduce the new name or combination concerned, that is, who does not state that he is introducing a new name or combination."

Item 34. Emendation of Rule $12 f$ (page 67). Rule $12 f$ was emended at the Montreal Congress by addition of the following note:

"Note. The phrase "epithets published in legitimate combinations" is to be interpreted under the provision of Rule 24." 
Item 35. Emendation of Rule 13 (page 70). Rule 13 was emended by the addition of a new paragraph (b) relating to impure or mixed cultures. The revised rule reads: "Rule 13. The name of a genus or subgenus is not validly published:

(a) Unless it is accompanied (1) by a description of the genus or subgenus; or (2)-by citation of a previously and effectively published description of the genus as a subgenus (or subgenus as a genus); of (3) in the case a monotypic new genus based on a new species, by a combined generic and specific description of one or more species included in the genus.

(b) If the description of the genus was based upon studies of impure or mixed cultures, that is, if there is evidence that the description was based on the properties of more than one species grown in a mixed culture. This statement does not apply to the name of a genus or subgenus whose description is based upon morphology or other characters and not upon growth in pure culture.

Note. A description of a new species assigned to a monotypic new genus is treated also as a generic description if the genus is not described. Similarly a description of a monotypic new genus based on a new species is treated also as a specific description if the generic name and specific epithet are published together and the species is not separately described."

Item 36. Emendation of Rule 15a (page 73). At the Montreal Congress the Commission instructed the Editorial Board to include a Note to Rule $15 \mathrm{a}$ to indicate that where more than two individuals are designated as coauthors of the name of a taxon it is appropriate to cite the name of the first author followed by "et al." (et alii). The emended rule reads:

"Rule 15a. For the indication of the name (unitary, binary, or ternary) of a taxon to be accurate and complete, and in order that the date may be readily verified, it is necessary to cite the author (or authors) who first validly published the name in question.

Note. Where multiple authorship of the article in which the new name of a taxon is published is evident, and there is no definite designation of a single individual as author of the name, the citation may be made by listing the names of all of the authors, or by giving the name of the senior author followed by the abbreviation "et al." (et alii)." 
Item 37. Emendation of Recommendation 15 (page 75). A

Recommendation, $15 \mathrm{c}$, was approved at Montreal to read: "Recommendation $15 \mathrm{c}$. When a publication having several authors contains names of taxa for which authority should be cited, it is urged that one of the authors should be definitely designated for citation as author."

Item 38. Emendation of Rule 21 (page 85). Minute 40 of the meeting of the Judicial Commission at Montreal, 1963, reads:

"The Judicial Commission approved the emended Rule 21 with instructions to the Editorial Board that a Note should be appended specifically authorizing the Judicial Commission to make exceptions to the rule when there are wellestablished subspecific names contrary to the rule. In the discussion it was pointed out that the name Mycobacterium tuberculosis subsp. (var.) hominis is quite firmly fixed in the literature, and might be conserved."

The emended Rule 21 , with Notes, reads:

"Rule 21. When several species are united as subspecies (varieties) under one specific name, or when a species is divided into subspecies, the subspecies which includes the type of the species must be designated by the same epithet as the species.

Note 1. The proposal of a subspecific name which excludes the type of the species, automatically creates another subspecific name which includes the type. The author of the species name is to be cited as the author of such automatically recognized subspecific name.

Note 2. The Judicial Commission has authority to make exceptions to the rule, where there is a well-established subspecific name not in accordance with the rule."

Item 39. Emendation of portions of Rule 24 (page 91).

Emendation of Rule 24 is here proposed as follows:

Rule $24 \mathrm{~b}$ reads: "[ The name of a taxon is illegitimate] if it is a binary or ternary name published in contravention of Principle 9 and Rules 17-23, i.e., if its author did not adopt the earliest legitimate epithet available for the taxon with its particular circumscription, position and rank."

Proposed emendation of Rule 24b:

"[ The name of a taxon is illegitimate] If it is a binary or ternary name published in contravention of Principle 9 and Rules 17-23, i.e., if its author did not adopt the earliest legitimate generic name, specific epithet, or subspecific 
epithet, available for the taxon with its particular circumscription, position and rank."

Proposed emendation of Rule 24d:

Substitute "taxon" for "group" in line 7.

Proposed emendation of Rule $24 \mathrm{~g}$ :

"[The name of a taxon is illegitimate] If the characteristics of the taxon were based upon studies of impure or mixed cultures, that is, if there is evidence that the description was based on the properties of more than one species grown in mixed culture. This statement does not apply to the name of a species or subspecies whose description is based upon morphology or other characters not dependent upon cultivation in pure culture."

Proposed emendation of Rule 24h:

The present statement reads: "[The name of a taxon is illegitimate] if it was based upon an abnormality."

To be deleted.

Item 40. Emendation of Rule 25 (page 95). Proposal of emendation to introduce "such epithet" for "it." The emended rule would read:

"Rule 25. A specific or subspecific epithet is illegitimate in the following special cases, and must be rejected:

(a) When such epithet is merely a word not intended as a specific epithet.

(b) When such epithet is merely an ordinal adjective used for enumeration.

(c) When such epithet exactly repeats the generic name (tautonym).

(d) When such epithet is a later homonym within the same genus, that is, when it duplicates a specific or subspecific epithet previously and validly published for a species or subspecies of the same genus, based upon different type."

Item 41. Emendation of Rule 25 (page 95). Deletion of Rule $25 \mathrm{e}$ is recommended. The present rule reads: "e. When it was published in a work in which the Linnaean system of binary nomenclature for species was not consistently employed."

Item 42. Emendation of Rule 25 (page 96). It is proposed that the following Note be added to Rule 25:

"Note. A specific epithet is not rendered illegitimate by publication in a species name in which the generic name is illegitimate. 
Item 43. Emendation of Note to Rule 26 (page 97). The Note appended to Rule 26 was approved at the Montreal Congress to read:

"Note. When a new epithet is required an author may, if he wishes, adopt an illegitimate epithet previously given to the taxon (in an illegitimate combination) if there is no obstacle to its employment in the new position or sense; the resultant combination is treated as a new name and ascribed to its author."

Item 44. Emendation of Recommendation 27a (page 107).

Emended at the Montreal Congress by inclusion after

"Latin form" the parenthetical (latinization). The

Recommendation 27 a then reads:

"When a name or epithet for use in bacteriological nomenclature is derived from a Greek word, the transliteration to Latin form (its latinization) should conform to classic usage. Appendix A (q.v.) to this Code may be used as a guide. If a later author corrects in a valid publication the spelling of a name or epithet incorrectly transliterated from the Greek, this correctly spelled word may be regarded as an orthographic variant of the name or epithet."

Item 45. Emendation of Recommendation 27c (page 107), approved at Montreal:

"For scientific names of taxa it is advisable to use another font from that used for the remainder of the text, or to space the letters, or to use some similar device appropriate to the text. Typescript of scientific names should be underlined, to indicate that when printed they should appear in a different font, preferably italics."

Item 46. Emendation of Recommendation 27f (page 113).

Approved at Montreal to read:

Provisions of Recommendation $27 \mathrm{e}$ apply to an epithet formed from the name of a woman. When the epithet has a substantival form, it is given a feminine ending."

Item 47. Emendation of Recommendation $27 \mathrm{~g}$ (page 114).

Approved at Montreal to read:

"A new specific or subspecific epithet should be written in conformity with the original spelling of the word from which it is derived and in strict accordance with the rules of Latin and latinization." 
Item 48. Emendation of Recommendation 27h (page 114).

Approved at Montreal to read:

"A specific epithet, even one derived from the name of a person, should not be written with a capital letter."

Item 49. Emendation of tital of Chapter 4 (page 123). The present title does not adequately cover the scope of the Provisions. It is proposed that the text of the title be changed to read:

"Provisions for Organization and Administration of the International Code of Nomenclature of Bacteria and for the Inte rpretation and Modification of its Rules."

Item 50. Emendation of Provision 1 (page 123). The reorganization of the: International Association requires recognition of the successor of the Plenary Session of the previous organization. The appropriate name should be inserted if there is no longer a Plenary Session. The present Provision 1 reads:

"Modification and Amendment of the Code. This Code can be amended only by action of the International Committee on Bacteriological Nomenclature and approval of a Plenary Session of an International Congress for Microbiology convened by the International Association of Microbiological Societies."

Item 51. In Provision 2, emendation of the first paragraph "Lists of nomina conservanda" (page 123), correction of a typographical error. In the second line replace the word "genera" by "taxa."

Item 52. Emendation of first paragraph of Privision 4, headed "Permanent International Committee on Bacteriological Nomenclature". (page 124). At the Montreal Congress this first paragraph was emended to read as follows (modifications are underlined):

"A permanent International Committee on Bacteriological Nomenclature has been established by the International Association of Microbiological Societies in Congress. This Committee is so constituted that wherever practicable each country is represented by at least one member and no country by more than five. Nominations for membership are made preferably in each nation by the microbiological society which is the national member of the International Association of Microbiological Societies (IAMS). The national 
member is defined in Article 3 of the Statutes of IAMS, 1962. Nominations should be made in writing to one of the permanent secretaries of the Committee. Acceptance will be indicated by the Secretary and the nominees given temporary membership on the Committee pending action of the Committee and of the next International Congress when election will be confirmed. If suitable national or regional microbiological societies or organizations do not exist, a primary nomination for a country not represented may be made by one of the Permanent Secretaries. When elected such members shall serve until nominations are made by a national or regional microbiological society.

Membership on the International Committee is of indefinite tenure. It may be terminated by resignation, death, request of the nominating organization, or by a continued failure to participate in the work of the Committee.

Item 53. Emendation of Provision 4 (page 125). At the Montreal Congress the four words "At least.one year" were deleted from the second paragraph on page 125 . The emended sentence now reads:

"Before each Congress each national society shall inform the Permanent Secretaries of any recommendations relative to changes in its representation."

Item 53. Emendation of Provision 4, paragraph beginning on page 125 and continuing to the middle of page 126, with the heading "Functions of the International Committee." This statement was emended at the Montreal Congress to read as follows (emendations underlined):

"The International Committee on Bacteriological Nomenclature has the following functions:

(1) To hold meetings at the time of and as part of the sessions of each Congress of the International Association of Microbiological Societies.

(2) To consider and pass upon all recommendations made by the Judicial Commission relative to the formulation, the modification, or the emendation of the International Code of Nomenclature of Bacteria or relating to the nomenclature of other groups of microbiological concern. In cases in which the approval of the International Association of Microbiological Societies (IAMS) is also necessary, the Committee will make the appropriate recommendations. Proposals for emendation of the Bacteriological Code shall be submitted to one of the Permanent 
Secretaries in sufficient time to allow publication in the International Journal of Sy stematic Bacteriology at least 3 months before the next following International Microbiological Congress.

(3) To receive all Opinions issued by the Judicial Commission. Each Opinion of the Judicial Commission is final unless there is filed a formal objection in which case the International Committee shall determine acceptance or rejection or take other appropriate action. Action by the International Committee shall be taken at the meeting of the Committee next following the date at which the Opinion was published and submitted to the Committee. Alternatively a decision may be made by the International Committee by letter ballot.

(4) To authorize, appoint and outline the functions of special subcommittees of experts to consider and make recommendations concerning the nomenclature of bacteria and to report on other phases of their taxonomy.

(5) To sponsor a section on taxonomy and to organize one or more sessions of such section at each Inte rnational Congress, at which sessions there will be opportunities for presentation and discussion of reports of the several subcommittees on taxonomy.

(6) To receive and transmit to the Judicial Commission for publication the reports of the several subcommittees on taxonomy and to refer to the Judicial Commission any special problems that have been raised or recommendations that have been made respecting nomenclature.

(7) to elect from the membership of the Committee the members of the Judicial Commission as vacancies may occur and to replace the members of the several classes as their terms expire.

(8) Whenever a vacancy occurs, to nominate a Permanent Secretary.

(9) To appoint as Life Members of the International Committee on Bacteriological Nomenclature individuals who have rendered distinguished service to bacteriological nomenclature and taxonomy. Such life members shall be regarded as members-at-large and not as representing the microbiologists of any nation.

Item 55. Emendation of Provision 4 (Election of Chairman and Vice Chairman of the International Committee) (page 126). Emendation of the title of the paragraph is proposed to read:

"Election and Duties of Chairman and Vice Chairman." 
Item 56. Emendation of Provision 4 (Election of Chairman and Vice Chairman) (page 126). Emendation approved at Montreal. Under "Duties of the Chairman":

"A. (2) To collaborate with the Chairman of the Judicial Commission, with the Vice Chairman, and with the two Permanent Secretaries in the preparation of all agenda for the meetings of the International Committee (ICBN)."

Emendation approved at Montreal. Under "Duties of the Vice Chairman":

"B. (2) To collaborate with the Chairman of the Committee, the Chairman of the Judicial Commission and the two Permanent Secretaries in the preparation of all agenda for the meetings of the International Committee (IC BN)."

Item 57. Emendation of Provision 4, Election of two Permanent Secretaries (page 127). The last two lines of the first paragraph were replaced by the following:

"The Permanent Secretaries are voting members-atlarge and shall not be included in the quota of any nation."

Item 58. Substitution of "General Meeting" for "Plenary Session." At Montreal there was approval of a change in wording where applicable in the Code from "Plenary Session" to "General Meeting" to conform to the 1962 Statutes of the International Association of Microbiological Societies (IAMS).

Item 59. Emendation of Provision 4, Duties of Permanent Secretaries (page 127). At Montreal emendations of paragraphs (1), (4), (5), (7) and (8) were approved to read:

(1) To prepare, in cooperation with the Chairman of the Committee, the Vice-Chairman of the Committee and the Chairman of the Judicial Commission the agenda for all meetings of the Committee and of the Judicial Commission.

(4) To transmit to the Committee from the Judicial Commission such recommendations as may require action by the Committee; in the intervals between international congresses to duplicate and send such recommendations to all members of the Committee. If the members of the Committee are circularized to secure comments and suggestions, to tabulate the information received. If the 
members are asket to vote upon any proposal, to tabulate and announce the result of the ballot and to certify the result to the Chairman of the Committee and to the Chairman of the Judicial Commission.

(5) With the Chairman of the Judicial Commission and the Editorial Secretary to serve as members of the Editorial Board to edit and prepare for final publication all Opinions issued by the Judicial Commission, also the International Code of Nomenclature of Bacteria and its emendations, and all of the publications authorized by or sponsored by the Committee or by the Judicial Commission.

(7) To present to the general meeting of the Congress all actions of the Judicial Commission and of the International Committee requiring approval, including lists of names of members with addresses.

(8) One or the other of the permanent secretaries shall be a member of each subcommittee on taxonomy authorized or appointed by the International Committee (ICBN) for the purpose of maintaining liaison between the subcommittee, the International Committee on Bacteriological Nomenclature and the Judicial Commission. He shall receive from the secretary of the subcommittee and transmit to the International Committee and to the Judicial Commission reports and recommendations of the subcommittee.

Item 60. Emendation of Provision 4. Duties of Permanent Secretaries (page 128). Emendation of (9) to read as follows is proposed:

(9) With the chairman to authorize the formation of new subcommittees to consider the nomenclature and classification of special groups of microorganisms, such subcommittees to have provisional status only until such time as they may be duly authorized by action of the International Committee on Bacteriological Nomenclature (ICBN). (Remainder of paragraph transferred to Item 61.

Item 61. Emendation of Provision 4. Election and Duties of an Editorial Secretary (page 128). At the Montreal Meeting of the International Committee (ICBN) the position of Editorial Secretary was created by the election of an Editorial Secretary. However there was included in the motion no list of functions or duties. The following proposal is intended to make place in Provision 4 for the 
position of Editorial Secretary with a statement as to duties:

Appointment and Duties of an Editorial Secretary. An Editorial Secretary is chosen by the Inte rnational Committee and confirmed by the General Meeting of the International Association of Microbiological Societies (IAMS). A vacancy in the office of Editorial Secretary which may occur in the interim between Congresses of the International Association of Microbiological Societies shall be filled by the Judicial Commission, such appointment to be temporary until confirmed by the International Committee. The Editorial Secretary is a member-at-large of the International Committee on Bacteriological Nomenclature and shall not be included in the quota of any nation. The Editorial Secretary serves as Editorial Secretary for the Judicial Commission and as a member of the Editorial Board of the Judicial Commission.

Item 62. Emendation of Provision 4, Functions of Taxonomic Subcommittees (page 128). It is proposed that the title "Functions of Taxonomic Subcommittees" be changed to read:

"Organization and Functions of Taxonomic Subcommittees."

Item 63. Emendation of Provision 4, "Organization and Functions of Taxonomic Subcommittees" (page 128). Emendation of the first paragraph is proposed to read: "Proposals for the formation of Taxonomic Subcommittees may be made by an individual or by a group of individuals to one of the Permanent Secretaries. Such a request should be accompanied by a statement of the proposed duties of the subcommittee and ra list of the members proposedio Taxonomic Subcommittees of experts authorized and appointed by the International Committee on Bacteriological Nomenclature shall work under the following rules:

(1) Members of a Subcommittee. The chairman of the Nomenclature Committee, with the two Permanent Secretaries of that committee, will select the members of the new taxonomic subcommittee from names submitted and other names. They will also appoint a temporary chairman and secretary to carry on the work with the members of the taxonomic subcommittee until such time as the subcommittee can elect its chairman and secretary, and revise the membership. 
(2) The chairman and secretary of each subcommittee on taxonomy shall be elected by the members of the subcommittee and shall hold office through two consecutive International Microbiological Congresses. They shall be eligible for reelection.

(3) One or other of the Permanent Secretaries shall be designated as a nonvoting member of each subcommittee and shall act as liais on between the subcommittee, the International Committee, and the Judicial Commission.

(4) Each taxonomic subcommittee shall meet at each International Microbiological Congress and shall regularly review and revise its membership. The names of members who have resigned or who have ceased to interest themselves in the work of the taxonomic subcommittee shall be deleted from the membership list.

(5) The Chairman and Secretary of each taxonomic subcommittee are responsible for the preparation and presentation of a report through the liaison Permanent Secretary to the International Committee. This report, if accepted by the International Committee, may be published in the International Journal of Systematic Bacteriology. The report should include a review of work during the period following the meeting of the preceding International Congress together with copy of the minutes of the meeting held during the current Congress. The list of members of the subcommittee as revised shall be submitted to the liaison secretary immediately following each Microbiological Congress.

(6) A taxonomic subcommittee may ask collaborators to study particular problems. Collaborators need not themselves be members of the subcommittee.

(7) It is proposed that No. 7 (page 129) be deleted as unnecessary interference in the autonomy of committee action. The statement reads:

"When votes are called for in subcommittees or subgroups, the simple majority shall suffice; in the event of a tie, the chairman shall have a casting vote. If members wish to record a unanimous decision, a fresh vote may be called for. Votes shall be recorded by a show of hands unless a secret ballot is demanded by at least one-quarter of the members present.

(7) (New) The primary functions of a taxonomic subcommittee are two: (1) to undertake and encourage research on the relationships of the organisms of the several units and subdivisions of the taxon under study, developing 
the reby better classifications from the practical standpoint of identification, without ignoring the significance of contributions to a better understanding of phylogeny, and (2) to advise and make recommendations relative to nomenclature. The subcommittees are encouraged to use any and all of the techniques of the several branches of science in recognition of characters useful in distinguishing the bacteria studied. The appropriateness of modification of rules and recommendations of the Bacteriological Code should be noted and proposals for emendation believed desirable made to the Judicial Commission. * The preparation of monographs of taxonomic groups is desirable. Particularly significant is recognition of type species of genera and type strains of species and of subspecific taxa, likewise establishment of neotype strains of species and subspecific taxa, and the deposit of these reference strains in culture collections where they are available for distribution. Likewise important is the formulation of better nomenclatural treatment and taxonomy of the infrasubspecific forms.

(8) Members who cannot attend meetings of subcommittees may designate alternates to act for them. An alternate shall be provided by the member with written authority to record a vote on the member's behalf."

Deletion is recommended of the last sentence which reads: "Expert observers who do not have voting rights may be introduced by members."

(9) Deletion is proposed of (9) which reads:

"Between Congresses the work of the subcommittees will be conducted by correspondence. When votes are called for each ballot paper will be signed by the member. Unsigned papers will not be counted."

Item 64. Emendation of Provision 5, Authorization of a

Judicial Commission (page 130). Emendation of the first paragraph is proposed by insertion of the statement:

"The Editorial Secretary of the International Committee (ICBN) is also Editorial Secretary of the Judicial Commission."

The proposal reads:

* While a stabilized classification cannot be legi ated or created by fiat, in most areas a reasonably satis. zctory stabilized taxonomy may be developed through conseasus. 
"A Judicial Commission is authorized. It shall consist of fourteen members, twelve elected by the members of the International Committee on Bacteriological Nomenclature (ICBN) from its membership and the two Permanent Secretaries. The Editorial Secretary of the International Committee on Bacteriological Nomenclature is also the Editorial Secretary of the Judicial Commission. The Commissioners are elected to serve in three classes of four Commissioners each, one class retiring at the close of each International Congress of the International Association of Microbiological Societies."

Members of retiring classes are eligible for reelection.

"In case of the resignation or death of a Commissioner between Congresses, the vacancy may be filled by letter ballot of the members of the International Committee.

Item 65. Emendation of Provision 5, Duties of the Chairman of the Judicial Commission (par. 5, page 130). Proposal to emend Paragraph 5 to read:

"With the cooperation of the Permanent Secretaries and the Editorial Secretary to formulate tentative Opinions and proposals either for discussion or vote by members of the Judicial Commission and to receive and codify or tabulate the results. With the cooperation of the Permanent Secretaries and the Editorial Secretary to put in form for consideration requests or suggestions for emendation of the International Code of Nomenclature of. Bacteria, to circulate such requests or formulations to the Commissioners, to call for votes, to tabulate them, and to make appropriate recommendations to the International Committee on Bacteriological Nomenclature.

Item 66. Emendation of Provision 5, Functions of the

Judicial Commission (page 131).

Proposal: Delete from (2) (page 131) "and viruses"

Proposal: Replace the second paragraph on page 132

by the following rewording:

"In suitable cases an Opinion shall be prepared and if approved by 8 or more Commissioners, shall be issued and published, becoming thereby available for the guidance of bacteriologists. All Opinions are reported to the International Committee on Bacteriological Nomenclature (ICBN) and unless rescinded by a majority vote of this committee such Opinions are final." 
Item 67. Emendation of Provision 5, Functions of the

Judicial Commission (page 132).

Proposal: Replace the first sentence of (3) by the

following:

"To consider each proposal for emendation of the International Code of Nomenclature of Bacteria and to formulate a recommendation for such emendation."

Item 68. Emendation of Provision 5, Functions of the

Judicial Commission, (4) (page 132).

Delete (4) page 132. This provision has never been used. If strictly enforced it would greatly handicap the ordinary procedures in the issuance of Opinions. The fact that all Opinions are referred to the International Committee and may be rescinded by action of this Committee is believed to be adequate safeguard.

Item 69. Emendation of Provision 5, Functions of the

Judicial Commission, (5) (page 132).

Replace the first sentence of (5) by the following:

"To establish a list of the names of taxa that are to be conserved (nomina conservanda) on the basis of Opinions issued relative to the status of such names."

Delete the remainder of (5).

Item 70. Emendation of Provision 5, Functions of the

Judicial Commission, (6) (page 133).

Retain the first sentence of $(6)$ which reads:

"To prepare and publish lists of types which have been fixed through issuance of Opinions of the Judicial Commis sion."

Delete remainder of (6).

Item 71. Emendation of Provision 5, Functions of the

Judicial Commission (10) (page 133).

Delete (10) page 133.

Item 72. Emendation of Provision 5, Functions of the

Judicial Commission (page 134). Proposed addition to

the Functions of the Judicial Commission:

"To sponsor or establish such publications, bulletins, journals or monographs as may be deemed advisable and approved by the International Committee on Bacteriological Nomenclature for the advancement of systematic bacteriology, including the International Code of Nomenclature of 
Bacteria. Under the sponsorship and direction of the Judicial Commission, the immediate supervision of publications is assigned to the Board of Publications."

Item 73. Emendation of Provision 5, Functions of the Judicial Commission (page 134). Proposal of an additional number under the title "Functions of the Judicial Commission" to read as follows:

"No. _ Organization and Functions of a Board of Publications.

(a) A Board of Publications of the Judicial Commission is authorized.

(b) The membership of the Board of Publications shall include the Chairman of the Judicial Commission, who shall be Chairman of the Board, the editor or editors of publications authorized by the Judicial Commission, the Permanent Secretaries and the Editorial Secretary.

(c) Functions of the Board of Publications. The Board of Publications shall coordinate the Editorial Boards that may be authorized by action of the Judicial Commission. Until such time as there are authorized editorial boards chosen for the International Journal of Systematic Bacteriology, the International Code of Nomenclature of the Bacteria, or other sponsored publications, the Publications Board will serve as the Editorial Board for all publications not having designated editorial boards.

The Board of Publications shall make pertinent recommendations for the establishment of editorial boards for the various publications to the Judicial Commission for appropriate action. 
